\title{
ВІДБІР ТА СТРУКТУРУВАННЯ ЗМІСТУ НАВЧАЛЬНОЇ ІНФОРМАЦІЇ
}

Устінова В. О. Відбір та структурування змісту навчальної інформації.

У статті розглянуто проблему відбору та структурування змісту навчальної інформації. Розкрито сутність понять «структура», «моделювання», «структурування». Висвітлено способи структурування змісту навчання у вищому навчальному закладі. Подано аналіз технології структурування навчальної дисципліни.

Ключові слова: структурування, структуралізм, структурування змісту гуманітарних дисциплін, гуманітарні технології, навчальна інформація.

Устинова В. А. Отбор и структурирование содержания учебной информации.

В статье рассматривается проблема отбора и структурирования содержания учебной информации. Раскрыта сущность понятий «структура», «моделирование», «структурирование». Освещены способы структурирования содержания обучения в высшем учебном заведении. Представлен анализ технологии структурирования учебной дисциплины.

Ключевые слова: структурирование, структурализм, структурирование содержания гуманитарных дисциплин, гуманитарные технологии, учебная информация.

Ustinova $\mathrm{V}$. A. The selecting and structuring the content of educational information.

The article considers the problem of selecting and structuring the content of educational information. The meanings of concepts are «structure», «modeling», «structuring».

Key words: structuring, the humanities' content structuring, humanitarian technologies, educational information.

Починаючи 3 другої половини XX століття, науковціі активно досліджують одну 3 ключових проблем сучасної дидактики - відбір та структурування змісту навчальної інформації. Різні наукові підходи та візії щодо розв'язання зазначеного питання знайшли своє віддзеркалення у працях В. Бєлікова, М. Данилова, Ю. Діка, Л. Занкова, Л. Зоріної, А. Крутських, В. Мощанського, В. Розумовського, К. Сосницького, А. Сохора, А. Умана, А. Усової, В. Шаталова, П. Ерднієва та інших.

Meта статті - проаналізувати підходи науковців щодо процесу відбору та структурування змісту навчальної інформації, визначити ефективні способи структурування змісту філологічних дисциплін у навчально-виховному процесі.

У наукових роботах педагогічної спрямованості поняття «структурування» трактується як процес, у якому складники навчального матеріалу відбираються відповідно до цілей освіти, упорядковуються за змістом і формою, вибудовуються за відповідними взаємозв'язками, адаптуються до пізнавальних можливостей студентів й об'єднуються з урахуванням певного педагогічного задуму, а також конкретної навчальної ситуації у єдине смислове ціле. 3 урахуванням багатогранності поняття «структурування» підходи до компонування навчального матеріалу довкола основних ідей науковці трактують по-різному: інтерактивний принцип змісту освіти (Я. Скалкова); принцип тематичної концентрації змісту навчального матеріалу (Е. Страчар); укрупнення дидактичних одиниць (А. Ерднієв), діяльнісний та 
системний підходи моделювання дидактичної теорії (П. Гусак) та ін. На наш погляд, їх сутність зводиться до єдиного положення - структурувати навчальний матеріал так, щоб усі теорії, категорії, поняття поєднувались в одну систему й доповнювали один одного. У кінцевому підсумку передбачається добитися засвоєння студентами знань, які дозволяли б вільно оперувати поняттями й категоріями, уміння використовувати знання у практичній діяльності.

Дослідник Р. Олійник наголошує на домінуванні у процесі структурування змісту навчальної дисципліни таких цілей, як:

- створення такої структури виучуваного матеріалу, яка виявилася б найбільш раціональною й ефективною задля його розуміння, засвоєння та запам'ятовування;

- уведення до створюваної структури способів ущільнення матеріалу, його згортання й розгортання;

- унесення до навчального матеріалу елементів навчально-пізнавальної діяльності, засвоєння яких забезпечить розвиток самостійності студентів;

- розподіл навчальної інформації у вигляді послідовності тематичних ареалів за главами, параграфами, розділами, лекціями (для кожного з цих структурних елементів визначаються мета, основні поняття й спосіб контролю знань).

Зазначені цілі можуть змінюватися, доповнюватися й характеризуватися специфічними особливостями, які визначаються спрямованістю навчальної дисципліни, контингентом студентів, а також майбутньою професією студентів. 3 метою систематизації цілей i відповідних до них завдань вибудовується «дерево цілей», що становить порівневе (від загального до конкретного) завдання цілей навчання, виховання та розвитку майбутнього спеціаліста.

В енциклопедичній та науковій літературі термінологічна одиниця «структура» визначається як сукупність сталих зв'язків між великою кількістю компонентів об’єкта, що забезпечують його цілісність і самототожність [3, с. 382].

Моделювання - це дослідження об'єктів, систем, явищ, процесів шляхом побудови й вивчення їх моделей.

Структурування $\epsilon$ процесом одержання або надання чому-небудь структурної організації. Структурування охоплює великий спектр понять та процесів, у той час як моделювання спрямоване на створення певної моделі, у якій може бути відображена відповідна структура знань або реальні об'єкти для удосконалення способів керування ними.

Поняття структурування має витоками часи стародавньої Греції та вчень Піфагора, Аристотеля, а також Платона, хто уперше обгрунтовує систему освіти й виховання молоді на основі досвіду афінської та спартанської систем виховання і вносить значний вклад у галузь структурування знань.

Не менш важливими у формуванні теоретичних засад структурування знань виявляються наукові положення Аристотеля, який розробив логічний апарат пізнання навколишнього середовища, уводить термін «універсалії» на позначення загальних понять, абстрагованих від реальності речей, зауважуючи, що «для отримання цих абстракцій ми починаємо 3 речей, що пізнаються, і переходимо до речей більш зрозумілих і які пізнаються».

До латентного періоду формування концепції ієрархізації знань також належать наукові роботи Імануїла Канта, Огюста Конта, Томаса Куна, Ернста Маха та ін. Зарубіжні філософи неодноразово наголошували на необхідності формальної систематизації результатів пізнавальної діяльності людини, й у значній мірі сприяли формуванню на початку XX ст. наукового напряму в гуманітарному знанніструктуралізму (від лат. structura - будова), що намагається аналізувати як складну 
систему взаємопов'язаних частин, певну специфічну галузь. Наприклад, два основних розділи у структуралістському літературознавстві - структурна лінгвістика i структурна поетика (І. Бодуен де Куртене та Ф. Соссюр), досліджують не звуки, слова і граматичні форми, які вивчаються літературознавством як таким, а закони, що реалізуються в мові та літературі.

У 60-х роках XX ст. філософські інтерпретації структуралізму поширюються й осмислюють перехід гуманітарного знання на абстрактно-теоретичний рівень та його зближення 3 природознавством, пропонуючи такі процедури й методи наукового пізнання, що передбачають:

- виокремлення первинної множини об'єктів, які передбачають наявність єдиної структури;

- розчленування об’єктів на елементарні сегменти (частини), у яких типові, повторювані взаємозв'язки пов'язують різнорідні пари елементів; виявлення в кожному елементі істотних для такого відношення реляційних властивостей;

- 3'ясування відношень між елементами системи та побудова іiі абстрактної структури шляхом безпосереднього синтезування або формально-логічного й математичного моделювання;

- розкриття відношень перетворення між сегментами, їх систематизація та побудова абстрактної структури шляхом безпосереднього синтезування або формально-логічного та математичного моделювання, а потім виведення із структури усіх теоретично можливих наслідків (конкретних варіантів) та перевірка їх на практиці;

- теоретичне передбачення можливого механізму реалізації зазначеної системи та наслідків усього процесу, а також перевірка їх на практиці.

Комплексне використання зазначених течій надає підстави для виокремлення двох способів структурування - змістового та процесуального. У контексті нашого дослідження для змістового структурування предметом усебічного вивчення $\epsilon$ навчальний матеріал, а для процесуального - етапи навчання. Ураховуючи позиції Д. Юма, О. Конта, І. Бодуена де Куртене, результатом процесуального структурування знань прийнято уважати поле знань, яке визначається як умовний опис основних понять і категорій навчальних предметів у їх взаємозв'язку, що можуть бути представлені у вигляді тексту, таблиць, схем після завершення процесу виокремлення знань на стадії структурування [4, с. 77].

Науковці П. Підкасистий і Б. Коротяєв зазначають, що відбір навчальної інформації, яка подана задля засвоєння, віддзеркалює логіку процесу пізнання та його результати, технологію процесів розпізнання явищ, їх упорядкування й систематизації, а також виявлення й пояснення сутності явищ. Предметом наукового інтересу А. Сохора $є$ дослідження впливу логічних зв'язків (відношень) у навчальному матеріалі на дидактичні властивості різних варіантів його пояснення. У роботі «Логічна структура навчального матеріалу. Питання дидактичного аналізу» науковець репрезентує структуру навчального матеріалу як систему, послідовність, взаємозв'язок складників, що становить єдине ціле. На його думку, залежність зазначених варіантів зумовлена тим, що ми розуміємо під елементом навчального матеріалу, і як установлюються зв'язки між їх множинністю. Зауважимо, що способом наочного подання таких структур $є$ логічні схеми, у яких елементами знання $€$ поняття, думки, закони, найважливіші досліди.

А. Усова й В. Беліков окреслюють такі критерії зв'язків між елементами, а саме:

1) наявність причинно-наслідкових відношень між елементами; 
2) зв'язок між основними, так званими родовими поняттями, і їх похідними);

3) функціональні зв'язки між елементами;

4) зв'язок між елементами, один з яких входить до складу іншого .

У процесі аналізу, виявлення й конструювання структури навчального матеріалу неминуче постає питання про їі оптимальність, що вимагає від науковців необхідності спиратися на принципи впорядковування системи знань. Л. Занков під час розгляду питань систематичності навчання уважає, що не можна перебувати у стані суперечності із системою й логікою відповідної науки. М. Данилов відзначає, що логіка навчального предмета, яка відображає логіку відповідної науки, характеризується системою наукових понять, які входять до програми курсу, послідовністю їх розташування й характером зв'язків між ними. Отже, науковець основою логічної структури змісту навчального матеріалу уважає систему понять, при цьому питання про логіку відповідної науки в цьому випадку залишається відкритим.

Л. Зоріна, уводячи в дидактику поняття системних знань як знань, структурно адекватних науковій теорії, стверджує, що під час їх відбору 3 основ теорії орієнтиром, що спрямовує й коригує відбір, може слугувати такий дидактичний принцип - орієнтація на цілісність, системність засвоєння провідної дидактичної одиниці. Мінімальний зміст основ теорії повинен бути необхідним і достатнім для того, щоб відобразити цілісну їі структуру.

Л. Зоріна стверджує, що кожен елемент теорії, будучи пов'язаним з іншим, має в той же час свій власний зміст, усередині якого функціонують властиві йому зв'язки, які залежать від виду знання й додають йому цілісності і структурності [1, с. 17].

Аналіз наукових досліджень 3 проблеми доводить, що в основі структурування змісту будь-якої навчальної дисципліни лежить технологія структурування ії змісту. Це процес, який полягає в логічній побудові навчального матеріалу та спрямований на опрацювання, цільову орієнтацію наукових знань і їх адаптацію до навчальних умов. Накопичений педагогічний досвід дозволяє дослідникам виокремити декілька способів структурування навчальної інформації, які найбільш ефективно зарекомендували себе в шкільній та вишівській практиці. Так, російський дослідник Л. Самойлов апелює до таких способів структурування змісту навчання у вищому навчальному закладі, як:

1. Спосіб послідовного узагальнення матеріалу, що вивчається, по частинах i його поетапної інтеграції у певну теоретичну цілісність. Як демонструє практичний досвід, зазначений спосіб структурування може бать ефективним тільки за умови ретельно продуманої організації навчально-пізнавальної діяльності студентів з боку викладача, коли аудиторний час використовується не для вивчення окремих аспектів, а для сприйняття, систематизації й осмислення, узагальнення й закріплення отриманої інформації.

2. Рух від заданої в загальному вигляді цілісної структури до оброблення та конкретизації іiі елементів. Зазначений спосіб може застосовуватися у виші при вивченні аксонометричних i дедуктивних теорій. Розширення сфери його використання дозволяє посилити дедуктивне начало у викладі матеріалу, вивести студентів вже на перших заняттях на ключові ідеї та узагальнювальні схеми, які можуть бути використані як опорні сигнали.

3. Оформлення матеріалу, що вивчається у вигляді опорних схем (спосіб В. Шаталова). Такі опорні конспекти, які містять у собі ідею згортання й розгортання навчальної інформації, виконуються у вигляді наочних схем, де репрезентовано одиниці інформації (факти, ідеї, поняття тощо), що підлягають засвоєнню, та простежені різноманітні зв'язки між ними. 
4. Конструювання цілого шляхом розкриття історії пізнання або ретроспективний аналіз розвитку наукових ідей у будь-якій галузі. У цьому випадку студенти приходять до розуміння того, як недоліки існуючих у науці моделей призводять до суперечностей теорії і практики, зумовлюючи передумови для виникнення нових гіпотез і теоретичних положень.

5. Відтворення логіки наукового розвитку проблеми з моменту іiі зародження. Навчальний матеріал структурується так, щоб виокремити і продемонструвати хід логічного пошуку наукових знань ученого у певній галузі.

6. Рух у напрямку від фактів до ядра теорії (поняття, моделі, закону, принципу), далі до висновку, наслідків, експериментальної перевірки висновків, ущільнення теорії та іiі практичного застосування (В. Розумовський). Дослідник зауважує, що зазначений спосіб, який заснований на загальноприйнятій методології розвитку знань (циклічності процесу пізнання).

7. Технологія укрупнення дидактичних одиниць, яка успішно розробляється й широко впроваджується у практику П. Ерднієвим. Укрупнена дидактична одиниця (УДО) визначається як локальна система понять, що об'єднуються на основі їх смислових логічних зв'язків і утворюють цілісну одиницю інформації, що засвоюється.

А. Мартинюк акцентує увагу на найбільш ефективних способах структурування змісту філологічних дисциплін у навчально-виховному процесі педагогічного коледжу, а саме: ущільнення змісту навчального матеріалу, що реалізується шляхом використання оперативних схем дій або алгоритмів (за П. Гальперіним), ідеї глобальних, укрупнених тем, що представлені у вигляді «основних одиниць засвоєння» (за П. Гальперіним, Д. Ельконіним), методу укрупнення дидактичних одиниць і досягнення раннього узагальнення (за В. Давидовим, Д. Ельконіним).

Слід зазначити, що широко відомим способом структурування є опорні сигнали й опорні конспекти В. Шаталова та його послідовників - мнемонічні схеми, прийоми та правила, що становлять наочне відображення предмету (дії), яке використовується для полегшення довготривалого запам'ятовування інформації. Засновані на феномені ідентифікації словесного образу та тексту, що грунтується на принципах ідеї опори й методичних знахідок у дидактиці В. Сухомлинського, вони також віддзеркалюють логічну структуру навчальних текстів.

Установлення відношень підпорядкування й супідрядності між видовими й родовими поняттями, відмінностей за певними ознаками, використання аналогій дозволяє будувати класифікаційні схеми.

Не менш поширеними способами структурування $\epsilon$ також моделювання навчального матеріалу та його репрезентація у вигляді матеріальних (фізичних й аналогових) та ідеальних моделей (інтуїтивних і знакових), візуалізація навчальної інформації за допомогою, а також використання функцій мультимедіа, гіпертексту, Інтернету.

Кожний із зазначених способів структурування навчальної інформації може репрезентувати різноманітні форми подання інформації: логічну, продукційну, фреймову й семантичну. Так, прикладом логічної форми $є$ символічний запис математичних аксіом і теорем з використанням логіки предикатів. Продукційна - це набір правил або алгоритмічних наказів для подання певної процедури вирішення задач. Семантична форма подається знаннями із використанням графів, блок-схем, рисунків тощо. Фреймова складається 3 декількох комірок-слотів, кожний з яких має своє призначення.

У структуруванні навчальної дисципліни, що здійснюється різними способами, 
закладена стратегія навчання, яка й зумовлює можливості формування цілісної навчально-пізнавальної діяльності індивідуума. Проблема структурування неминуче пов'язана 3 пристосуванням навчальної інформації до пізнавальних можливостей студентів, проте подібну адаптацію не слід сприймати лише як їі спрощення, оскільки вона містить певною мірою також елементи проектування пізнавальних труднощів, долаючи які студенти закріплюють отримані знання, засвоюють нове вміння й підіймаються на новий, більш високий рівень свого професійно-особистісного розвитку.

Проблема науково обгрунтованого відбору та структурування навчального матеріалу з урахуванням гносеологічних, психолого-педагогічних, герменевтичних, аксіологічних та інших фундаментальних принципів продовжує залишатися актуальною в сучасній дидактиці.

\section{Література}

1. Зорина Л. Я. Системность - качество знаний / Л. Я. Зорина. - М. : Знание, 1976. - 64 с. 2. Каган М. С. Гуманитаризация образования как общекультурная проблема / Моисей Самойлович Каган // Magister = Магистр. - М., 1998. - № 4. C. 88-95. 3. Педагогика : Большая современная энциклопедия/ [сост. Е. С. Рапацевич]. - Мн. : Современное слово, 2005. - 720 с. 4. Сохор А. М. Логическая структура учебного материала. Вопросы дидактического анализа / А. М. Сохор. - М. : Педагогика, 1974. - 192 с. 5. Фуртак Б. Л. Структурування змісту в сучасних австрійських і українських підручниках з математики і фізики для середньої школи : автореф. дис. на здобуття наукового ступеня канд. пед. наук : 13.00.09/ Фуртак Богдана Любомирівна . - К., 2001.- 23 с.

$$
\text { УДК } 378.011 .3-051(44)(043.3)
$$

\section{Тетяна Харченко}

\section{ПРИКЛАДИ ВИКОРИСТАННЯ ПРОБЛЕМНИХ СИТУАЦИЙ У ПРОЦЕСІ НАВЧАННЯ ВЧИТЕЛІВ У ФРАНЦЇ̈}

Харченко Т. Г. Приклади використання проблемних ситуацій у процесі навчання вчителів у Франції.

У статті виявлено практичні аспекти використання проблемних ситуацій у процесі навчання вчителів у Франції. Розкрито окремі форми й методи проблемноситуативного навчання, а саме: лекція, в основі якої знаходиться проблемна ситуація, методики «Двійник», «Дзеркало».

Ключові слова: Франція, проблемно-ситуативне навчання, особистість учителя, педагогічна освіта, розвиток.

Харченко Т. Г. Примеры использования проблемных ситуаций в процессе обучения учителей во Франции.

В статье выявлены практические аспекты использования проблемных ситуаций в процессе обучения учителей во Франции. Раскрыто отдельные формы и методы проблемно-ситуативного обучения, а именно: лекция, в основе которой находится проблемная ситуация, методики «Le Sosie», «Зеркало».

Ключевые слова: Франция, проблемно-ситуативное обучение, личность учителя, педагогическое образование, развитие.

Kharchenko T. G. Samples of applying problem situations in teachers' academic process in France. 